Article

\title{
Urban Arrival Infrastructures between Political and Humanitarian Support: The 'Refugee Welcome' Mo(ve)ment Revisited
}

\author{
Rivka Saltiel \\ Institute of Geography and Regional Science, University of Graz, 8010 Graz, Austria; E-Mail: rivka.saltiel@uni-graz.at
}

Submitted: 15 February 2020 | Accepted: 25 June 2020 | Published: 28 July 2020

\begin{abstract}
Maximilian Park in Brussels was the site of a makeshift refugee camp for three months in 2015 when the institutional reception system was unable to provide shelter for newly arriving asylum seekers. Local volunteers stepped in, formed a civic initiative and organized a space of arrival under the banner 'Refugees Welcome!' The civic platform which emerged claimed and asserted (existing) rights for one specific group, asylum seekers, exclusively, and thus did not challenge the exclusive migration regime nor demand transformation. While such a humanitarian approach risks reproducing the exclusive border regime and the inequalities it engenders, political support is a disturbing rupture in the name of equality that resists normative classifications and inaugurates transformation. This article maps out the complex dialectical interrelation between political and humanitarian support and argues that political implications can only be understood through longerterm research, emphasizing processes of transformation that have resulted from these moments of disruption. Therefore, the article revisits Maximilian Park two and four years after the camp and reveals how the humanitarian approach chosen in the camp sustainably transformed the park, adding arrival infrastructures beyond the institutional, and had an impact on how refugees were dealt with and represented. Concluding, the article suggests the notion of 'solidary humanitarianism' that providing supplies, meeting acute existential needs and simultaneously articulating political claims that demand structural transformation: the right to shelter, basic supply, presence, and movement for all in the city.
\end{abstract}

\section{Keywords}

arrival policies; Belgium; Brussels; humanitarianism; irregular migration; solidarity; space of arrival; transmigrants

\section{Issue}

This article is part of the issue "Urban Arrival Spaces: Social Co-Existence in Times of Changing Mobilities and Local Diversity" edited by Yvonne Franz (University of Vienna, Austria) and Heike Hanhörster (ILS-Research Institute for Regional and Urban Development, Germany).

(C) 2020 by the author; licensee Cogitatio (Lisbon, Portugal). This article is licensed under a Creative Commons Attribution 4.0 International License (CC BY).

\section{Introduction}

A young man approaches us, asking us in English if we could help him. This question irritates me, as does his demanding approach. I reply, asking him how could I help him? Now it seems that I have irritated him. In poor English, he again asks me, if I could help him. Not knowing how to respond and without any clue of his expectations, I again ask, how could I help him. After this question was exchanged again and again Thomas intervenes asking if they'd need any support when the police come in the evening as announced to 'clear up the park.' He turned down this offer and we continue the question-game and eventually after I reformulate the question explicitly asking what he wants or needs, he points to my jacket. It's the end of September in Brussels, the evenings are chilly and the nights are cold. I explain that I only brought one jacket with me to Brussels so I can't give it away. He lists other things: food, drinks, a sleeping bag.

I try to direct the discussion again in a political direction, asking whether we should organize with other local activists to impede the police's entry to the park. Rejecting this, he explains that any contact with the police is to be avoided and when informed, 
they leave the park and return several hours later, once the police have left. (author's research diary, 21 September 2017)

The man I met in Maximilian Park in the center of Brussels, departed from Eritrea passing through Brussels on his way to his chosen terminus of Great Britain. Approaching me, a female middle-class student from Austria entering the park with a (also western European male) friend, he expected material donations-essentials for survival. He did not want to address the constant threat of police violence, detention centers or deportation - the structural mechanisms and inequalities that caused his precarious situation in the first place. This encounter illustrates the main arguments of this article. First, the question "How can you help me?" and the subsequent dialogue point to the ambiguity of support-both humanitarian and political. Second, it indicates a transformation of Maximilian Park, its meaning, its use, and the expectation attached to one's presence there, since the events of 2015, when the public park was the site of a makeshift refugee camp.

After an interruption of the governmental reception procedure in August 2015, local volunteers (citizens as well as registered and undocumented 'non-citizens') came to support the newcomers building and organizing an informal refugee-camp in Maximilian Park. In the making of the camp, the civic initiative Plateforme Citoyenne de soutien aux Réfugiés (Citizens' Platform in Support of Refugees; henceforth referred to as Platform) was formed and it took the lead in organizing the whole camp. Hosting up to 1,000 refugees, the camp lasted for three months. Only once the federal government again guaranteed shelter for all asylum seekers did the Platform withdraw from the park, after which the camp was dismantled.

In the 'long summer of migration' (Kasparek \& Speer, 2015), institutional infrastructures failed to accommodate the high number of arriving refugees not only in Belgium but throughout Europe. This period of disruption lead in many cities (and borderlands) to arrival spaces where refugees were left without any institutional support. Under the motto 'Refugees Welcome' a manifold of civic initiatives emerged to fill the gaps, supporting the newcomers, and some might say supporting the state too (see van Dyk \& Misbach, 2016, for critical discussion on the governmental instrumentalization of community resources and unpaid labor legitimized by the 'state of emergency'). These diverse activities included, amongst others, organizing arrival spaces, hosting refugees in private homes, organizing language courses, and creating buddy systems.

A growing body of (predominantly German) scholarly discussion has emerged in recent years reflecting on the summer of 2015, the motives of the volunteers to engage (Frykman \& Mäkelä, 2019; Hamann \& Karakayali, 2016; Karakayali \& Kleist, 2015, 2016), the structure and the mode of organization of the initiatives that emerged
(Karakayali \& Kleist, 2015, 2016), as well as the use of ICT and social media to communicate, organize and create networks (Koca, 2016; Sutkutè, 2019). Furthermore, scholars have elaborated on the chances and possibilities these spaces and moments opened up to enact alternatives to the usual procedure of institutionalized professional asylum reception. They argue that these new spaces of encounter provide chances for the creation of relationships and friendships between locals and newcomers that facilitate processes of 'integration' (Aumüller, Daphi, \& Biesenkamp, 2015; Fleischmann \& Steinhilper, 2017; Hamann \& Karakayali, 2016; Heins \& Unrau, 2018).

While in Germany, chancellor Angela Merkel called on German society for support in filling the emerging gaps in the institutional refugee supply, claiming 'We can do it!' (Wir schaffen das!), the sociopolitical climate in Belgium was different and, as in many other European countries, governmental authorities took an anti-refugee stance. Attempting to dissuade asylum seekers from applying to stay in the country, Theo Francken the state secretary for asylum and migration (from the right-wing Flemish Nationalist Party) sent out semi-official letters stating the government's inability to provide housing and assistance for newcomers (Vandevoordt \& De Praetere, 2016). Further, the government decided to limit the asylum-registrations to a maximum of 250 per day, leaving hundreds of asylum seekers with no institutional supply. Under these circumstances, civic welcoming initiatives were subverting the government's approach "not so much through the form in which they manifest themselves, but through their implicit opposition to the ruling sociopolitical climate" (Vandevoordt \& De Praetere, 2016, p. 17).

Moreover, emphasizing the disruptive and potentially transformative effects on migrant discourses and representations (Fleischmann \& Steinhilper, 2017), the widespread engagement of local people in welcoming refugees demonstrates an endorsement of the newcomers and a statement against rising xenophobic and racist inclinations (Benček \& Strasheim, 2016; Vandevoordt \& De Praetere, 2016). Welcoming refugees disrupts discourses of migrants as a threat to culture and/or security (Darling, 2014; Hermann \& Neumann, 2018; Walters, 2004). However, the humanitarian logic substituted these imaginaries by its representation of dependent poor victims in need of care and support (Darling, 2013; Pupavac, 2008; Ticktin, 2006; Walters, 2006). Thus, migrants find themselves reduced to being mere objects of either pity or hatred (Rancière, 1998, pp. 31-32), in either case, excluded from political partaking and deprived their political subjectivity (Isin \& Rygiel, 2007).

Consequently, the transformative potential of 'Refugees Welcome' is limited, since it identifies the 'poorest,' choosing asylum seekers (preferably Syrian women and children) as worthy of support, while other immigrants are often not welcomed and are again excluded (Fleischmann \& Steinhilper, 2017; Pupavac, 2008; 
Saltiel, in press; Ticktin, 2006). 'Refugees Welcome' claims compliance with rights, as guaranteed by national and international law for one specific group. Such a humanitarian approach, even if subversive and disruptive to some extent, does risk reproducing the exclusive border regime and the inequalities it engenders. Therein lies the difference between the humanitarian moral and the ,political' in Rancière's (1992, 1998, 2001, 2016) understanding, that is a radical disturbing rupture, an intervention into the visible and sayable in the name of equality which resists normative classifications.

This article maps out the complex dialectical interrelation between political and humanitarian support. I argue, that political implications can only be understood through longer-term research, with an emphasis on processes of transformation (spatial and temporal) that have (or have not) resulted from these moments of disruption (Dikeç \& Swyngedouw, 2017; Kaika \& Karaliotas, 2014; Swyngedouw, 2014). The article aims to add to the discussion on the disruptive, transformative potential of civic 'Refugees Welcome' initiatives by adding a longerterm perspective, which has remained absent from the debate until now. It revisits the site of the refugee camp, as well as the civic initiative that emerged, two (2017) and four years (2019) later revealing how the humanitarian approach chosen in the Camp Maximillian sustainably transformed the park, adding arrival infrastructures beyond the institutional, and had an impact on how refugees (not merely asylum seekers) were dealt with and represented in Brussels.

I suggest an understanding of 'solidary humanitarianism' that, next to providing humanitarian services reacting to acute existential needs, articulates political claims and inaugurates transformation. A 'solidary humanitarian' approach demands the right to existential supply, the right to housing, the right to movement and presence-the right to the city for all. Not dwelling on socio-legal subject positionalities, it does not reproduce the exclusive border regime nor the classifications it engenders-neither in uncritically supporting governmental 'crisis responses' (in the case of Germany) nor in merely opposing them/the lack thereof (in Belgium).

This article starts with revisiting Rancière's (1992, $1998,2001,2016)$ political-police dialectic, to understand how the border regime and the humanitarian moral act within the logic of the 'police.' This is followed by an examination of the perspective of 'Autonomy of Migration,' that emphasizes migrants as powerful political agents, framing their movement as a mode of interruption. Autonomy of Migration provides an alternative to the dominant discourses of victimhood and criminalization, stressing the political autonomy and agency of migrants, opening up possibilities for solidarity. Drawing on Dikeç and Swyngedouw's (2017) differentiation between political and social movements, the subsequent section analyzes two movements that address issues of migration movements ('No Borders' and 'Refugees Welcome') that took two different approaches and alter regarding their political potential. This analysis not only illustrates what separates a humanitarian moral from a political claim but also points to the limits of Rancière's conceptualization in activist practice regarding the dilemma of classification and identification. Once the methodological approach is presented, the processes in and around Maximilian Park are discussed with respect to the interplay between humanitarian aid and political support. Emphasizing transformations implied by the events of 2015 , it starts with the emergence of the refugee camp in 2015, followed by an exploration of the park and the Platform four years later in 2019. The article concludes with a discussion on the Platform's strategy and its limitations, eventually proposing the notion of 'solidary humanitarianism.'

\section{Police vs. Political: The Antagonistic Notion and Its Transformative Implications}

Rancière (2016) defines the 'police' regime as a highly exclusive force instituted by the post-political consensus arrangement. This hegemonic order divides societies into groups "dedicated to specific modes of action and legitimizes forms of domination and hierarchies of places and people" (Rancière, 2001, Thesis 7). Instituting "regimes of sensibility," the 'police' symbolically and materially define what makes sense; what is visible, sayable, audible, and thinkable; it defines what is and excludes what is not (Rancière, 2001, Thesis 7). Those who are positioned outside of the consensus are radically excluded and literally placed outside the law, treated as criminals, extremists, or terrorists. Their voices are muted to prevent the politicization (and subjectivation) of their particulars (Miessen \& Mouffe, 2012, pp. 19-21; see also Rancière, 2016; Swyngedouw, 2007, 2011).

The antagonist of the 'police' is the 'political.' It is the moment when the 'police' are challenged, disturbed, and interrupted (Rancière, 2001). In the name of equality, it performatively makes visible the "wrong of the given situation" (Swyngedouw, 2011, p. 374; see also Dikeç, 2017). The 'political' is not conceived around already given identities (Rancière, 2001), rather it is the "rejection of an identity established by another" (Rancière, 1998, p. 29) and thus it "entails an impossible identification" (Rancière, 1992, p. 62).

Rancière's conceptualization provides an apt framework to discern political moments (from the postpolitical condition; the 'police' regime). However, his momentous notion, with no concerns about its implications, falls short in understanding disruptive moments in their full iterations. In line with Swyngedouw (2011) and Dikeç (2012), I am concerned with lasting transitions, a new mode of organizing society, which was initiated by these events and their (cl)aim to universalize egalitarian presumptions (see also Dikeç \& Swyngedouw, 2017; Kaika \& Karaliotas, 2014). Concentrating on their transformative capacities, I consider these disruptive moments rather as momentum, as impulses. Moreover, emphasizing the 
aspect of spatial transformation that results from political moments. Swyngedouw (2011, p. 376) stresses that the political is inherently spatial, "[it] unfolds in and through the transformation of space, both materially and symbolically, redefining what constitutes public or private space and its boundaries and re-choreographs sociospatial relations."

\section{The Border Regime and the (Impossible) Identification}

The (inter)national border regime divides people into citizens and non-citizens. It further divides non-citizens into desired tourists or ex-pats, selects refugees eligible of humanitarian protection and excludes those who are not entitled to the rights of asylum, tourist or workvisa/permits. The latter are pushed into a life of illegality, losing their right to societal and political involvement. Creating hierarchical categories, identifying, allocating and excluding individuals, the border regime is considered as a manifestation of the 'police.' Through measures of securitization, individuals are represented (and maintained) as a threat or as patients, either way, they are externalized, objectified, and de-politicized (Nyers, 2010; Swyngedouw, 2007).

But "being political does not stop at the border" (Rygiel, 2012, p. 814). Scholars of the activist-research nexus Autonomy of Migration offer an alternative approach to frame migrant experiences and subjectivities in relation to the dominant discourses of security or victimhood. This theoretical approach is considered as an antidote to Giorgio Agamben's (2012) theory, that dominates discourses on refugees and camps, of the 'state of exception' that forces refugees into a bare, naked life. Agamben's account is criticized for ignoring the agonistic account of power-relations and disregarding migrants as political activists (Nyers, 2015; Walters, 2004). Rather than solely objects of exclusion or pity, Autonomy of Migration renders migrants as political agents (see also Isin, 2005, 2009; Nyers, 2015; Rygiel, 2011, 2012; Walters, 2006). Migration has the capacity to develop its own logics, motivations, and trajectories, which are countered by control, rather than the other way around (Papadopoulos \& Tsianos, 2013). Therefore, migration and movement are itself disruptive, resisting the postpolitical regime ('police') and thus, sites of migration are powerful political spaces that open up the potential for support, solidarity, and agency.

However, many forms of solidarity and agency (see Section 4) lead to greater visibility and increased attention that often comes with the downside of greater police presence (police here being the institutionalized state apparatus), and violence towards migrants (Rygiel, 2011 , p. 13). Thus, caution is required not to overstate migrants' agency or to ignore (or even romanticize) migrant realities and experiences and downplay the "repression and violence involved in border controls" (Nyers, 2015, p. 30). (Undocumented) Migrants' strategies to avoid- ing any attention from either the police or through solidarity, which might eventually lead to capture and deportation, need to be acknowledged (Tyler \& Marciniak, 2013, p. 148).

\section{Political and Social Movements? The Dilemma of Classification}

As outlined above, the "rupture of the 'normal' distribution of position" (Rancière, 2001, Thesis 3 ) is the very essence of the 'political.' A truly political mo(ve)ment resists the classifications of the 'police.' However, in practice, the revocation of categories, often involves-or even requires? - their reproduction. In this section two movements are discussed: 'No Borders' and 'Refugees Welcome.' Both resulted as reactions to moments of disruption when excluded individuals claimed their right to movement and presence. Although both entail the distribution of donations, they took different approaches.

In their analysis of urban insurgencies, Dikeç and Swyngedouw (2017) identify a shift from social to political movements. While the former base their claims on particular social positionalities and identitarian positions, the latter formulate universal demands for democracy, freedom, and solidarity. Conceptualized as a chronological sequence, this distinction proves equally conducive in the context of movements addressing issues of migration that exist simultaneously but differ in regard to their political potential.

'No Borders' aims for the abolishment of borders and the categories of inclusion and exclusion they produce but is confronted with quandaries in this endeavor. In establishing protest camps, they enact and dramatize the border as a site of power. By staging a different possible world, protest camps are effective instruments for political demonstration and political spaces of solidarity (Walters, 2006; see also Cantat, 2015; Darling, 2014; Nyers, 2015; Rygiel, 2011, 2012; Tyler \& Marciniak, 2013). 'No Borders' aim to interrupt a public discourse which casts migrants as speechless and invisible (Walters, 2006, p. 26). However, Kim Rygiel (2011) and William Walters (2006) both reported from the 'Jungle' in Calais of the difficulties on the part of the activists to include migrants in the coordination of the camp. Such statements impose the question of whether the citizen/non-citizen divide (be it strategically or in terms of the desired participation) can be completely abolished within its endeavors. Paradoxically, fighting national borders disallows an utter overruling (or negation) of the nation-state concept. What claim then is truly 'political' in disrupting hierarchical relationships, the concept of nation-state borders and/or the law? I tentatively put up for discussion: 'Whoever Welcome' that again risks dividing its actors between 'generous hosts' and 'guests,' or 'Free Movement for All' which problematically suggests temporary stays, as opposed to settling.

'Refugees Welcome' is a trans-European movement that emerged as a response to the influx of (predomi- 
nantly) Syrian refugees in 2015. While Koca (2016) argues that this movement arose as a reaction to global inequalities and against the border regimes (of the global North) that produce refugees, I argue that 'Refugees Welcome' is a status-/identity-based struggle that fails to challenge the 'police' since it reproduces the (categorization of the) border regime by definition ('Refugees Welcome!' vs. 'Whoever Welcome!'). It is not a fight for the political involvement of whoever (Rancière, 1998, $2001,2016)$, rather it is a demonstration of a generous attitude of members of a society towards certain Others, more precisely Syrian war refugees who are most likely to receive asylum. Therefore, it acts within an exclusive humanitarian discourse reducing (and representing) people as suffering victims worthy of humanitarian protection.

\section{Political Claim vs. Humanitarian Moral? Unravelling a Dialectical Relationship}

While a political claim is a claim of rights for those who have none through the demonstration of equality, humanitarian ethics are fundamentally unequal. It creates categories and readily defines 'poor suffering victims' (Ticktin, 2006). Thereby 'they' are being reduced to having only the identity of 'the Other' and the appearance of the excluded, losing political subjectivity and finding themselves being "mere object[s] of pity or, more commonly, hatred" (Rancière, 1998, pp. 31-32). Humanitarianism acts within the logic of the 'police' and reinforces state sovereignty since it "produce[s] (and depend[s] on) a particular form of subject: one that is excluded from politics" (Edkins, 2003, p. 256; see also Pupavac, 2008; Ticktin, 2006):

Humanitarianism...is defined as the cause of a naked humanity, as the defense of human rights that are identified solely with the rights of the victim, with the rights of those who do not have the means to assert their rights to use them to argue, a politics; in a word, a 'cause' of the 'other' that retreats from politics to ethics, and is then completely absorbed into duties towards the suffering. (Rancière, 1998, p. 31)

Edkins (2003), drawing on Campbell (1998), provides egalitarian prospects by suggesting a relational view on subjectivity; a recognition of the power-relations that every human is subjected to as the universal factor, rather than the Agamben's (2012) "naked humanity." She further argues with Foucault (1984) that we are all in solidarity because we are all governed. This cognition opens up the possibility for solidarity as a "protest against citizenship, a protest against membership of a political configuration as such" (Campbell, 1998, pp. 511-512). Being in solidarity, in turn, challenges structural mechanisms that construct power-asymmetries. It is then that humanitarian practice becomes 'political'; when and where identity-positions are resisted and equality is demonstrated (Rancière, 1998, 1992).

The section concludes with an ideal-typical dialectical juxtaposition of political claims and the humanitarian moral (see Table 1), that further provides the analytical framework to discuss the case of Maximilian Park.

\section{Maximilian Park: From Site of 'Crisis' to an Established Space of Arrival}

After a brief discussion of methodological considerations, this section provides insight in the empirical findings, first by elaborating on the formation of a structure and the emergence of an exclusive space of humanitarian aid in 2015 , followed by a discussion on the development and transformation which occurred following the events at the park and the creation of the citizens' platform there.

The so-called refugee crisis dominated medial, political, and societal discourses in the second half of 2015. I followed the re-action of city and state authorities as well as the emerging initiatives supporting the newcomers during that time. In September 2015, my Facebook News Feed was full of calls to engage in supporting the newcomers or pictures of people welcoming refugees. Most of my peers became active in one way or another, donating money, food, clothing, time, and labor, or by hosting migrants. Given my activist engagement in Rightto-the-City movements and my academic curiosity, it was inevitable that the sudden appearance in central public spaces of people who are usually marginalized would catch my attention.

However, my own mobility-I have moved three times to different European cities between September 2015 and January 2016-made engaging in refugee support difficult, and as such, I aim(ed) to contribute to the sociopolitical debate through academic positioning. Thus, I have retrospectively conducted research as of 2016 on spaces of arrival organized by civic 'Refugees Welcome' initiatives in Vienna (my country of origin, Austria) and in Brussels, where I lived as a student.

My 'non-presence' during 2015 provided a certain (emotional) distance to the subject under study and I first came to know Maximilian Park through narra-

Table 1. Political claim vs. humanitarian moral.

\begin{tabular}{ll}
\hline Political Claim & Humanitarian Moral \\
\hline Claiming the rights of those who have no rights & Looking for the poorest \\
Challenging normative categories through performance of universal equality & (Re)producing hierarchical categories \\
'Free Movement for All!' & 'Refugees Welcome!' \\
\hline
\end{tabular}


tives (gathered in interviews, conversations, and publications) about the camp. Since my focus lies on the citizens' platform that emerged there (one of several organizations, collectives, associations, and individuals present-many of whom were pursuing very different, diverging, and sometimes conflictual objectives in the camp), semi-structured interviews were conducted with members of the Platform (from volunteers who came once in a while, to members of the strategy group who dedicated their lives to the camp for the period of its existence). However, to obtain a broader picture and to understand the Platform's position and relevance within the camp, other actors were asked about their perspectives as well (employees of the humanitarian NGOs Médicins Du Monde and Vluchtelingenwerk), a member of CollectActif (a collective of Sans-Papiers that built a kitchen in the Park and provided the food for the camp), and an anarchist activist. Moreover, I discussed my empirical findings with fellow researchers who have written about Maximilian Park (see Action Research Collective for Hospitality, 2019; De Praetere \& Oosterlynck, 2017; Deleixhe, 2019; Vandevoordt \& De Praetere, 2016; Vertongen, 2018).

Additionally, in 2017 and 2019, insights were gained through participatory and non-participatory observation in the park and with the Platform. To convey the wideranging experiences in the field, I have chosen to formulate two passages as vignettes. Vignettes are conceived "as the written output of thick description" (Militz \& Schurr, 2016, p. 57). Such over-all situational descriptions allow for a framing that consists of more than words, including the researcher's body, her/his sensation, and affect (Creutziger, 2018, p. 141; Militz \& Schurr, 2016, p. 57).

The opening vignette stems from my very first inperson visit to Maximilian Park (in September 2017). My experiences and the encounter with the man, who had departed from Eritrea, surprised me, since (from what I had come to know) I considered the camp as a singular event, leaving no further traces in the Park, and it again fueled my interest in Maximilian Park, urging me to continue the research and to discuss the phenomenon's spatiality and temporality.

\subsection{The Refugee Camp in Maximilian Park: An Exclusive Space of Resolving a 'Crisis'?}

Maximilian Park lies in a central multi-ethnic neighborhood in Brussels, located next to the North Train Station, with social housing blocks to its north and office towers to its south. It is defined as a 'Priority Intervention Zone' and is undergoing vigorous building activities. Due to the arrival of many asylum seekers in the summer of 2015 , the Office of Immigration, facing the park, determined a limit of a maximum of 250 registrations per workday. This caused an accumulation of asylum seekers, not yet included in the reception-system, waiting day and night in the park to register. Locals gathered in support, bringing clothing donations, distributing food and pitching tents. In the first days, the camp was rather chaotic and seemingly anarchic, but soon hierarchical structures evolved. What had started as a Facebook group (named Plateforme Citoyenne de soutien aux Réfugiés), coordinated the volunteers, appealed for donations, eventually became a legal organization and the main actor in the Park. The exclusive core group of the Platform (strategy group) consisted of four 'white,' Belgian students. They held the decision-making power in the camp, they negotiated with politicians, cooperated (to varying degrees) with NGOs and other organizations, eventually even determining where to put what and who had access to the park and the services provided: in effect, they had power over who was included or excluded.

At the very beginning of the camp, autonomous left activists and Sans-Papiers activists were present in Maximilian Park, aiming to "politicize the camp" (Lukas, anarchist activist, Interview, June 19 ${ }^{\text {th }}, 2016$; for Sans-Papiers in the Park, see De Praetere \& Oosterlynck, 2017). The Sans-Papiers performed equality in a two-fold manner: First, as volunteers building a kitchen to provide food for the camp, they acted as citizens. Second, together with autonomous left activists, they performatively destabilized the differentiation between immigrants, making banners stating: 'The Refugees of today are the Sans-Papiers of tomorrow. All together the same battle!' They sought to combine the struggle of Sans-Papiers for papers with the 'refugee-crisis' and addressed the exclusionary dimensions of the migration regime making visible the wrong of the given situation (Swyngedouw, 2011, 2014). However, their political interventions did not fit with the Platform's idea of the camp, consequently, they were not acknowledged by it, sparked conflict and were (violently) excluded from the park.

The Platform's consensus was 'resolving the crisis' (Sofia, Strategy Group and Spokesperson of the Platform during the camp, interviewed 20 October 2016). They filled the gaps in the national reception system, reproducing its exclusivity by only providing care facilities for asylum seekers (not for any other people in need). Even though often portrayed as horizontally organized, the Platform quickly instituted an exclusive hierarchic mode of organization, establishing an internal 'police' system, preventing politicization and excluding those, who formulated political claims. Despite resistance, Maximilian Park turned into an exclusive space of humanitarian aid. The makeshift tent city went on to last for three months until the national infrastructure resumed the care provision and opened a shelter for all arriving refugees, and yet the events had a lasting impact on the park, its meaning, its use and the expectations attached to it.

\subsection{After the Camp: Maximilian Park and the Platform Revisited in 2019}

Passing by the park in the late afternoon I see hundreds of men and few women sitting, lying and/or 
sleeping on splayed cardboard boxes talking to each other or listening to music. The stench of urine is hardly bearable. There are no sanitary facilities-only one fountain. Wet clothes are hanging on the climbing scaffold and on the fences to dry. A young man, Zaid, approaches me. He wants to go to Great Britain 'to take the chance.' He moves between Brussels, Paris, and Calais repeatedly attempting the passage. Knowing his way around Brussels, Zaid prefers this city to others since he does not fear the police as much as in neighboring towns and because of its support infrastructure and networks. Sometimes he would also find shelter with a family or in a shelter of the Platform but he 'doesn't mind' sleeping in the Park-it is summer, as long as he can take a daily shower and wear fresh clothing. (author's research diary, 18 June 2019)

In 2019, four years after the camp, Maximilian Park is the address for immigrants arriving in Brussels. It is a space of arrival, for transit and rest, for establishing networks, for meeting traffickers, a space that allows for a brief pause on their journey. Identified as socalled 'transmigrants,' the people now present in the park do not seek asylum in Belgium (different to 2015), they are not officially registered and thus purported undocumented (or irregular) immigrants passing through Belgium on their way to the desired destination of Great Britain via Calais. Their layover is on average between six and twelve weeks (M. Kassou, employee Platform, interviewed 19 June 2019).

The Platform is still active, centering their activities around the park, providing food, water, or other donations. However, while in $\mathbf{2 0 1 5}$ the Platform filled the gap in the governmental supply system for asylum seekers, they now build arrival infrastructures beyond the institutional for 'transmigrants' (again exclusively for this one specific group, others in need are sent forward to different organizations in the city). After personnel replacements in the core group (due to internal conflicts, new professional obligations and other reasons) and an intense process of restructuring between December 2015 and December 2017, the Platform reinvented itself and professionalized. With 36 employees, thousands of volunteers and more than 55,000 Facebook followers, it became one of the biggest actors in Brussels and Belgium supporting irregular immigrants. Within a range of initiatives, together with established NGOs (Médecins du Monde, Médecins sans Frontières and the Red Cross), they created the 'Humanitarian Hub,' providing "all activities that respond to the needs of the migrants that are not taken care of by the government" (Médecins du Monde, 2019). These include psychological support, medical care, socio-legal advice, clothing, hygiene product distribution, and space to recharge batteries (both metaphysical and technological). The Platform also runs shelters hosting more than 460 individuals per night. Equally, a program of private harborage was set up, where about 250 people find shelter each night with one of several thousand families throughout Belgium.

A temporary police-free zone (state apparatus) is negotiated with the City of Brussels for times when members of the Platform are present in the park. Even though not constantly exposed to the threat of police raids and arrest, the Park is not a 'safe space.' Complex power-structures have emerged internally, including Mafia structures, which demand protection payments as well as payment for access to water at the fountain. Women (which represent $15 \%-20 \%$ of the individuals in the park; see Médecins du Monde, 2019) are particularly unsafe; since there is no sanitary infrastructure in the park, they need to undress in order to urinate or defecate. An employee of the Platform (interviewed 22 June 2019) explained, that there is a high rate of rape in the Park and that many women engaged in sex work to finance the onward journey, to pay traffickers, or for (male) protection. All these circumstances do often lead to a high number of pregnancies among the women who seek support in the Humanitarian Hub.

\section{Between Political and Humanitarian? A Strategic Differentiation}

Despite the migrants' irregular status, the Platform formulated a claim of access to care, however, it did not formulate a claim to political participation. The identification of people as 'transmigrants' eliminates political claims as it suggests their stay is temporary. The term was coined by Theo Francken (State Secretary for Asylum and Migration, from the right-wing Nationalist Flemish Party) to identify the people visible in the park as not entitled to receive services from the federal government. The Platform-aware of its origin-knowingly took up this fraught terminology (as did other NGOs and the media). The 'transmigrants' thus, formed a new category, even though they had no legal status, no papers and hence, no legal right to shelter, they were differentiated from the Sans-Papiers and positioned above them in the imagined ideological hierarchy of migrants. While Sans-Papiers are criminalized and illegalized, 'transmigrants' are selected to be worthy of care and humanitarian services.

The Platform regulates the presence of irregular immigrants. Their 'proper places' are redefined and restricted to the passage between the park and the Hub, private homes and shelters (Swyngedouw, 2014). The tension between the political and humanitarian realm also came to the fore in the self-awareness and subsequently in the communication strategies of the Platform. A strategic rhetorical differentiation of the political and the humanitarian realm can be discerned. In their communications, the Platform emphasized that they were not 'political' nor 'activists.' M. Kassou (interviewed 19 June 2019), formerly a businessman in a transnational electronic corporation, now an employee of the Platform, responsible for communication affairs, explains: "By telling the people: This is a political fight 
when they come to give food and their things to people you just scare them. They leave!"

The Platform's strategy (and aim) is to slowly generate a political movement from below and to eventually politicize their approach-which is now rather humanitarian (see Section 5) -through raising awareness about day-to-day realities of migrants: "And even if you know that it's a different fight, [a] political fight, that you're asking for different results. Knowing it doesn't mean that you have to say it like that. Don't do that! Be smart!" (M. Kassou, interview 19 June 2019).

The Platform acts within the logic of the 'police' in a manner that pleases thousands of volunteers and supporters as well as the local authorities. It is financed by the city of Brussels and the Brussels Capital Region. Hence, processes of downscaling responsibilities have taken place. While on the federal scale the right-wing parties withdrew from the situation, the center-left coalition that governs at the regional and city level in Brussels, act against their political opponents. The (due to the large contribution of free labor by volunteers, relatively cheap) care-provision of the Platform contributes to a certain level of control that acts in favor of the governing authorities. It prevents a feared re-establishment of the camp and reduces the visibility of homeless migrants in the urban public space and thus averts attention, politicization and/or disruption of the public life in the city.

Therefore, the Platform encounters a high degree of acceptance from a broad range of political parties on the regional and city level, from the left and the liberals. Mimicking the politicians, the political scientist Youri Vertongen (interviewed 23 June 2019), cynically states: "It's easier for us to get with the Platform because it is not a regularization issue, it's just helping and hosting people for some weeks. And we have money for it and the public opinion is great with it." This demonstrates the postpolitical logic of the establishment, the convergence of the positions of the right and the left, with the emergence of a common economic and political doxa and a managerial dispositive (Rancière, 2016; Swyngedouw, 2011).

\section{Towards 'Solidary Humanitarianism?'}

The initial question 'how can you help me?' and the subsequent dialogue pointed to the ambiguity of supportthe dialectic relationship between the political and the humanitarian realm. While theoretical debates insinuate that humanitarian and political support are mutually exclusive, the occurrences in and around Maximilian Park suggest a more complex relationship that is dynamic and context-specific. It is constantly re-negotiated in different moments, with different actors engaging and different institutional circumstances. The disruptive moments that occurred, were countered with humanitarian support and mechanisms of 'policing,' but nonetheless instigated lasting change in how irregular migrants are dealt with in Brussels. They triggered awareness and vast support in the Brussel's society and improved day-to-day re- alities for those who pass through (and temporarily stay in) Brussels.

The moment of disruption in the summer months of 2015 turned Maximilian Park into a refugee camp, a space of humanitarian care. Civic volunteers as opposed to 'experts' took the lead in organizing the space, thereby "perform[ed] the capacity to govern" (Swyngedouw, 2014, p. 128). However, the citizens' platform did not enact an alternative to the governmental mode of reception, neither did they demand its transformation, but rather reproduced the usual procedure. In selecting asylum seekers exclusively as those worthy of the provided services, the civic initiative with its humanitarian approach reenacted the exclusive migration regime as well as the inequalities it engenders. Asserting the consensus of 'solving a crisis,' the Platform instituted a regime of sensibility, allocating things and people (Rancière, 2001), averting political subjectivation and excluding those who antagonistically articulated political claims. Thus, first conclusions suggested that the establishment of the camp and the humanitarian stance taken did not have any political impact, did not lead to any transformation in the city of Brussels, once the asylum procedure was back in place.

Nevertheless, my visit two years later (2017, introductory vignette) proved, that the camp and the vast humanitarian support of autumn 2015 did entail long(er) lasting transformative impulses, shifting Maximilian Park and the expectations attached to it. Although, the Platform withdrew from the park, following the camp's closure and the reinstatement of institutional reception of all asylum seekers, the park substantially transformed into a space of arrival, of self-organization, as well as a point of reference for humanitarian activities. Dikeç (2012, p. 670) states that "politics inaugurates space, and spatialization is central to politics as a constitutive part of it." Therefore, space is conceived not only metaphorically, but as a mode of political thinking. At this time, however, the few people present in the park were not asylum seekers, but undocumented migrants with little chance of receiving asylum in Belgium and hence on transit to Great Britain. Their presence is criminalized. In seeking nonetheless presence in this public space, they are claiming their part in-and their right to-the city and refuse "to be restricted to the places distributed to them by the 'police' order [emphasis added]" (Swyngedouw, 2011 , p. 387), that would be outside the nation-state borders. Thus, their being in the park "disrupt[s] normative accounts of forced migration" (Darling, 2017, p. 180). The young man addressed me with very specific expectations: Humanitarian (material) support to ensure his survival. He would not risk attention (that might possibly lead to arrest) through political support or acts of solidarity that aim to fight the structural mechanisms that caused his precarious situation. Different logics of perception, questioning the post-political established status quo, arose from localized demands (Darling, 2013, p. 76) and the Platform reorganized and re-acted. After 
a period of restructuring, it still centers its activities around Maximilian Park, providing arrival infrastructures and humanitarian support, but addressing a different target group.

At my visit in 2019, I was again confronted with a completely different situation, when I saw hundreds of men and few women in the Park, spending their days and nights there. The professionalized Platform allocated all of their services in or within walking distance from the park. As opposed to 2015, they do now challenge the migration regime, claiming rights for those who do not hold rights to shelter, presence, or movementthey articulate demands for an alternative. The activities of the Platform with its thousands of volunteers and its cooperation with the city and the region of Brussels did transform how migrants are dealt with in this European Capital City. However, their engagement is again restricted to one specific group. Identifying, labelling, and choosing 'transmigrants' as worthy of support, while others in need are excluded, is clearly to be considered as a depoliticizing means within the logic of the 'police' regime. Furthermore, their demands have been-so far-chiefly to address the right to humanitarian support-not to political subjectivation, part-taking, or citizenship-rights.

The discussion of the development of Maximilian Park and the citizens' platform has demonstrated that humanitarian and political support are not necessarily mutually exclusive. Therefore, I propose the notion of 'solidary humanitarianism,' that does not choose between political or humanitarian support, rather it provides resources, meets acute existential needs, and simultaneously articulates political claims demanding structural transformation; a right to the city, right to shelter, and the supply of life's basics for all in the city. 'Solidary humanitarianism' is 'political' and radically inclusive. Rather than excluding the 'political' (to avoid conflict, scandal, and displeasing the establishment), humanitarian initiatives need to emphasize on and form alliances withgive a voice to-the excluded (both those who are denied access to shelter and care and/or those who fight for [radical] structural transformation). In order to create an alternative to existing infrastructures, a 'solidary humanitarian' approach democratizes the decision-makingprocesses. It is transparent and deals with the question of representation, even brings it to the fore and thereby challenges the dominant discourses of depoliticized migrant subjectivities and disrupts the dependency of individuals (and state authorities) towards charitable citizens and initiatives. Instead, it challenges the structural mechanisms that construct power-asymmetries legitimating exclusion, in the first place, entailing a protest against citizenship (Campbell, 1998). 'Solidary humanitarianism' claims the right to the city for everyone, for whoever takes (a) part in the city.

The Platform has an intention to gradually change the institutional frameworks from within, eventually formulating a universal claim for political involvement and against exclusionary nation-state regimes, à la 'No Borders, No Nations!' Whether or not this intention will succeed, remains an open question. The public Maximilian Park, however, transformed after the events of 2015. By 2019, it had become a space for immigrants arriving, staying, and transiting: a place of selforganization as well as a reference point for those in providing support, both humanitarian and political.

\section{Acknowledgments}

I would like to thank Anke Strüver, Nicolas Schlitz and Scott Durno-Couturier for their comments and support in different phases of writing. Thanks also to the two anonymous reviewers for their valuable comments and suggestions. I acknowledge the financial support of the University of Graz.

\section{Conflict of Interests}

The author declares no conflict of interests.

\section{References}

Action Research Collective for Hospitality. (2019). Whose future is here? Searching for hospitality in Brussels northern quarter. Brussels: Metrolab Series.

Agamben, G. (2012). Homo sacer: Die souveräne Macht und das nackte Leben [Homo Sacer: Sovereign power and bare life]. Frankfurt: Suhrkamp Verlag.

Aumüller, J., Daphi, P., \& Biesenkamp, C. (2015). Die Aufnahme von Flüchtlingen in den Bundesländern und Kommunen. Behördliche Praxis und zivilgesellschaftliches Engagement [Refugee reception in the federal States and the Communes. Official practice and civil society engagement]. Berlin: Robert Bosch Stiftung.

Benček, D., \& Strasheim, J. (2016). Refugees welcome? A dataset on anti-refugee violence in Germany. Research \& Politics, 3(4). https://doi.org/10.1177/ 2053168016679590

Campbell, D. (1998). Why fight: Humanitarianism, principles and post-structuralism. Millennium: Journal of International Studies, 27(3), 497-521.

Cantat, C. (2015). Contesting Europeanism: Migrant solidarity activism in the European Union. INTEGRIM Online Papers, 2015(8). Retrieved from https://www.integrim.eu/wp-content/uploads/ 2014/02/CANTAT-contesting-europeanism.pdf

Creutziger, C. (2018). Rauchzeichen und Zwischentöne. Unterwegs mit Zigaretten und Vignetten [Smoke signals and nuances. On the go with cigarettes and vignettes]. In F. Meyer, J. Miggelbring, \& K. Beurskens (Eds.), Ins Feld und zurück: Praktische Probleme qualitativer Forschung in der Sozialgeographie [In the field and back: Practical problems of qualitative research in social geography] (pp. 137-143). Berlin: Springer. 
Darling, J. (2013). Asylum and the post-political: Domopolitics, depoliticisation and acts of citizenship. Antipode, 46(1), 72-91.

Darling, J. (2014). From hospitality to presence. Peace Review, 26(2), 162-169.

Darling, J. (2017). Forced migration and the city: Irregularity, informaility, and the politics of presence. Progress in Human Geography, 41(2), 178-198.

Deleixhe, M. (2019). Biopolitical sovereignty and borderlands. Journal of Borderlands Studies, 34(5), 649-664. https://doi.org/10.1080/08865655.2017.1414623

De Praetere, A., \& Oosterlynck, S. (2017). 'I finally found my place': A political ethnography of the Maximiliaan refugee camp in Brussels. Citizenship Studies, 21(6), 693-709.

Dikeç, M. (2012). Space as a mode of political thinking. Geoforum, 43(4), 669-676.

Dikeç, M. (2017). Disruptive politics. Urban Studies, 54(1), 49-54.

Dikeç, M., \& Swyngedouw, E. (2017). Theorizing the politicizing city. International Journal of Urban and Regional Research, 41(1), 1-18.

Edkins, J. (2003). Humanitarianism, humanity, human. Journal of Human Rights, 2(2), 253-258.

Fleischmann, L., \& Steinhilper, E. (2017). The myth of apolitical volunteering for refugees: German welcome culture and a new dispositif of helping. Social Inclusion, 5(3), 17-27.

Foucault, M. (1984, June 30). Face aux gouvernements, les droits de l'homme. Libération, 967 [Governments Facing Human Rights; Press release]. Retrieved from https://www.fondamentaux.org/2013/michelfoucault-face-aux-gouvernements-les-droits-deIhomme

Frykman, M. P., \& Mäkelä, F. (2019). 'Only volunteers'? Personal motivations and political ambiguities within the refugees welcome to Malmö civil initiative. In M. Feinschmidt, L. Pries, \& C. Cantat (Eds.), Refugee protection and civil society in Europe (pp. 291-318). Cham: Palgrave Macmillan.

Hamann, U., \& Karakayali, S. (2016). Practicing willkommenskultur: Migration and solidarity in Germany. Intersections, 2(4). https://doi.org/10.17356/ieejsp. v2i4.296

Heins, V. M., \& Unrau, C. (2018). Refugees welcome: Arrival gifts, reciprocity, and the integration of forced migrants. Journal of International Political Theory, 14(2), 223-239.

Isin, E. F. (2005). Engaging, being, political. Political Geography, 24(3), 373-387.

Isin, E. F. (2009). Citizenship in flux: The figure of the activist citizen. Subjectivity, 29(1), 367-388.

Isin, E. F., \& Rygiel, K. (2007). Abject extrality: Frontiers, zones, camps. In E. Dauphinee \& C. Masters (Eds.), The logic of biopower and the war on terror: Living, dying, surviving (pp. 181-203). New York, NY: Palgrave Macmillan.

Kaika, M., \& Karaliotas, L. (2014). The spatialization of democratic politics: Insights from Indignant Squares. European Urban and Regional Studies, 23(4), 556-570.

Karakayali, S., \& Kleist, O. (2015). EFA-Studie: Strukturen und Motive der ehrenamtlichen Flüchtlingsarbeit (EFA) in Deutschland [EFA study: Structures and motives of voluntary refugee work in Germany]. Berlin: Berliner Institut für empirische Integrations und Migrationsforschung.

Karakayali, S., \& Kleist, O. (2016). EFA-Studie 2: Strukturen und Motive der ehrenamtlichen Flüchtlingsarbeit (EFA) in Deutschland [EFA study 2: Structures and motives of voluntary refugee work in Germany ]. Berlin: Berliner Institut für empirische Integrations und Migrationsforschung.

Kasparek, B., \& Speer, M. (2015). Of Hope: Ungarn und der lange Sommer der Migration [Of hope: Hungary and the long summer of migration]. Border Monitoring. Retrieved from https://bordermonitoring.eu/ ungarn/2015/09/of-hope

Koca, B. T. (2016). New social movements: "Refugees Welcome UK." European Scientific Journal, 12(2), 96-108.

Médecins du Monde. (2019). Le hub humanitaire de la gare du nord déménage au port de bruxelles [The Humanitarian Hub moves from the North train station to the Brussels' harbor]. Médecins Du Monde. Retrieved from medecinsdumonde.be/actualitespublications/actualites/le-hub-humanitaire-de-lagare-du-nord-demenage-au-port-de\#undefined

Miessen, M., \& Mouffe, C. (2012). The space of agonism: Markus Miessen in conversation with Chantal Mouffe. Berlin: Sternberg Press.

Militz, E., \& Schurr, C. (2016). Affective nationalism: Banalities of belonging in Azerbaijan. Political Geography, 54, 54-63.

Nyers, P. (2010). No one is illegal between city and nation. Studies in Social Justice, 4(2), 127-143. https: //doi.org/10.26522/ssj.v4i2.998

Nyers, P. (2015). Migrant citizenships and autonomous mobilities. Migration, Mobility, \& Displacement, 1(1), 23-39.

Papadopoulos, D., \& Tsianos, V. S. (2013). After citizenship: Autonomy of migration, organisational ontology and mobile commons. Citizenship Studies, 17(2), 178-196.

Pupavac, V. (2008). Refugee advocacy, traumatic representations and political disenchantment. Government and Opposition, 43(2), 270-292.

Rancière, J. (1992). Politics, identification and subjectivization. October, 61, 58-64.

Rancière, J. (1998). The cause of the other. Parallax, 4(2), 25-33.

Rancière, J. (2001). Ten theses on politics. Theory \& Event, 5(3). http://doi.org/10.1353/tae.2001.0028

Rancière, J. (2016). Politik und Ästhetik. Im Gespräch mit Peter Engelmann [Politics and aesthetics. In conversation with Peter Engelmann]. Vienna: Passagen Gespräche. 
Rygiel, K. (2011). Bordering solidarities: Migrant activism and the politics of movement and camps at Calais. Citizenship Studies, 15(1), 1-19.

Rygiel, K. (2012). Politicizing camps: Forging transgressive citizenships in and through transit. Citizenship Studies, 16(5/6), 807-825.

Saltiel, R. (in press). Care for and from whom? On the complexity of social relations in the Refugee Camp in Maximilian Park in Brussels 2015. Manuscript submitted for publication.

Sutkutè, R. (2019). Shaping of the public discourse on refugees in social media: "Refugees Welcome Lithuania." EUREKA: Social and Humanities, 1, 35-52.

Swyngedouw, E. (2007). The post-political city. In Collective BAVO (Eds.), Urban politics now: Re-imagining democracy in the neoliberal city (pp. 58-77). Rotterdam: NAi Publishers.

Swyngedouw, E. (2011). Interrogating post-democratization: Reclaiming egalitarian political spaces. Political Geography, 30(7), 370-380.

Swyngedouw, E. (2014). Where is the political? Insurgent mobilisations and the incipient 'return of the political.' Space and Polity, 18(2), 122-136.

Ticktin, M. (2006). Where ethics and politics meet: The violence of humanitarianism in France. America Ethnologist, 33(1), 33-49.

Tyler, I., \& Marciniak, K. (2013). Immigrant protest: An introduction. Citizenship Studies, 17(2), 143-156.

van Dyk, S., \& Misbach, E. (2016). Zur politischen Ökonomie des Helfens. Flüchtlingspolitik und Engagement im flexiblen Kapitalismus [On the political economy of helping. Refugee policy and engagement in flexible capitalism]. Prokla: Zeitschrift für kritische Sozialwissenschaft, 183, 205-228.

Vandevoordt, R., \& De Praetere, A. (2016). Subversive humanitarianism: Understanding the civil refugee support in Europe. Unpublished manuscript.

Vertongen, Y. L. (2018). Soutien politique et soutien humanitaire: Retour sur les solidarités citoyennes avec les réfugiées en Belgique [Political support and humanitarian support. Returning to the Citizens' solidarity with refugees in Belgium]. Mouvements, 93(1), 127-136.

Walters, W. (2004). Secure borders, safe haven, domopolitics. Citizenship Studies, 8(3), 237-260.

Walters, W. (2006). No border: Games with (out) frontiers. Social Justice, 33(1), 21-39.

\section{About the Author}

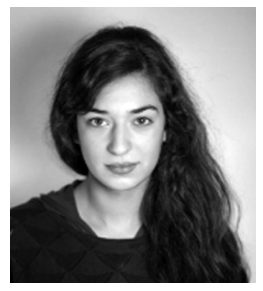

Rivka Saltiel is a Member of the Urban HEAP Research Group, based in the Department of Geography and Regional Science in Graz and is an Associate Researcher in the RCE Graz-Styria. She studied cultural anthropology and then completed the international 4cities Master's Program in Urban Studies. In her PhD project 'Space for Everyone: Utopia or an Emancipatory Political Project?' she elaborates on the transformative potential of urban spaces of encounter. 